\title{
Suitability Confirmation for Welding Ultra-High Strength Steel S1100QL Using the RapidWeld Method
}

Jaroslav Brabec ${ }^{1}$, Štěpán Ježek ${ }^{2}$, Libor Beneš ${ }^{1}$, Antonín Kříž ${ }^{3}$, Petr Majrich ${ }^{2}$

${ }^{1}$ Faculty of Mechanical Engineering, J. E. Purkyne University in Usti nad Labem. Pasteurova 3334/7, 40001 Usti nad Labem. Czech Republic. E-mail: jarolav.brabec@ujep.cz, libor.benes@ujep.cz

${ }^{2}$ Department of Manufacturing Technology, Faculty of Mechanical Engineering, Czech Technical University in Prague, Technická 4, Praha 6, Czech Republic. E-mail: stepan.jezek@fs.cvut.cz, ladislav.kolarik@fs.cvut.cz

${ }^{3}$ Faculty of Mechanical Engineering, University of West Bohemia in Pilsen, Univerzitní 22, 30614 Plzeň, Czech Republic. E-mail: kriz@kmm.zcu.cz

This experiment assesses the suitability of square-welding high strength steel using the deep penetration welding method, RapidWeld. The aim of this method suitability assessment was to compare the final material properties of three welds, welded accordingly to identical welding procedures. High strength, ultra-fine-grain steel S1100QL (XABO 1100) was used as a parent metal. The suitability confirmation was based on the achievement of requested mechanical properties of ISO 15614-1 and mobile crane manufactures standards. The hardness, strength properties and impact energy measurement and evaluatioon of the joint was performed during the experiment. The joint was welded repeatedly with the use of the same welding parameters for the confirmation of process stability. The achieved mechanical properties fulfill all the requirements. The hardness value deviation is caused by different properties in the heat affected zone. The root cause of the impact energy deviaton was not fully investigated, but the minimal measured values are above requirement. The deviation of the strength characteristics is mininal. The performed experiment has confirmed that the selected welding method is suitable to ensure that the requested material properties of welded high strength, ultra-fine-grained steel are achieved.

Keywords: High strength steel, t8/5, square groove welding, RapidWeld, S1100QL

\section{Introduction}

The utilization of high strength steel in the welded structures industry is a noticeable trend at the moment. The use of steel with high yield strength is beneficial for many reasons - one being that the total weight of the welded structure may be reduced by lowering the cross section of structure beams. The reduction of weight and cross section of the structure Tab. 1 The benefits of the use of the high strength steel for the steel structures [1]

Steel grade comparison for rectangular section $120 \mathrm{~mm} \times 80 \mathrm{~mm} \times \mathrm{t}$, longitudinally welded, $\mathrm{V}$-seam, bending moment $50[\mathrm{kNm}]$

\begin{tabular}{|l|c|c|c|}
\hline & S355J2C & Alform700M & Alform960 x-treme \\
\hline Sheet thickness & $15[\mathrm{~mm}]$ & $6[\mathrm{~mm}]$ & $4[\mathrm{~mm}]$ \\
\hline Weld seam volume & $100[\%]$ & $16[\%]$ & $7[\%]$ \\
\hline Laser cutting time & $100[\%]$ & $40[\%]$ & $27[\%]$ \\
\hline Required edge force & $100[\%]$ & $32[\%]$ & $19[\%]$ \\
\hline Minimum inside edge radius & $100[\%]$ & $24[\%]$ & $32[\%]$ \\
\hline Component weight & $100[\%]$ & $44[\%]$ & $30[\%]$ \\
\hline
\end{tabular}


Ensuring the correct thermal cycle is critical when welding high strength steel, with heat input being the main influencer $\mathrm{Q}\left[\mathrm{kJ} \cdot \mathrm{mm}^{-1}\right]$ (1). It is possible to reduce the negative impact welding has on materials and to achieve the requested mechanical properties of the joint by using appropriate heat input. $[1,3,4,5,6]$

$$
\boldsymbol{Q}=\boldsymbol{k} \cdot \frac{\boldsymbol{U} \cdot \boldsymbol{I}}{\boldsymbol{v}_{\boldsymbol{s v}}}\left[\mathrm{kJ} \cdot \mathrm{mm}^{-1}\right][2]
$$

In this equation $\mathrm{k}[/]$, the process of thermal efficiency, for GMAW $\mathrm{k}=0,8[/]$. $\mathrm{U}[\mathrm{V}]$ is voltage, $\mathrm{I}[\mathrm{A}]$ is the current used while welding, and $\mathrm{V}_{\mathrm{w}}\left[\mathrm{cm} \cdot \mathrm{min}^{-1}\right]$ is welding speed.

Heat input use while welding high strength steel is limited by the recommendations of the parent metal producer. With increasing yield strength, the area of suitable welding parameters is reduced. The recommendation of suitable welding parameters for various steel grades is in Fig. 1. [1,3]

Parameter $\mathrm{t}_{8 / 5}[\mathrm{~s}]$ is used to evaluate thermal cycles while welding high strength steel. Parameter $\mathrm{t}_{8 / 5}$ represents the cooling time of weld metal from $800^{\circ} \mathrm{C}$ to $500^{\circ} \mathrm{C}$. By effect of different cooling times, the parent metal, weld metal and heat affected zone contains various material structures. The $t_{8 / 5}$ value relies on the physical properties of material, design of the joint and heat input used while welding. It is possible to significantly reduce strength and toughness of welded joints if inappropriate heat inputs are selected. Correctly selected welding parameters should meet the parent metal producer's recommendation for the $t_{8 / 5}$ value. The $\mathrm{t}_{8 / 5}$ recommended value is $5-15$ [s] for S1100QL. Illustration of $t_{8 / 5}$ 's resulting influence on the material's structure and hardness HV1 of weld metal for steel S700MC is in Fig. 2.

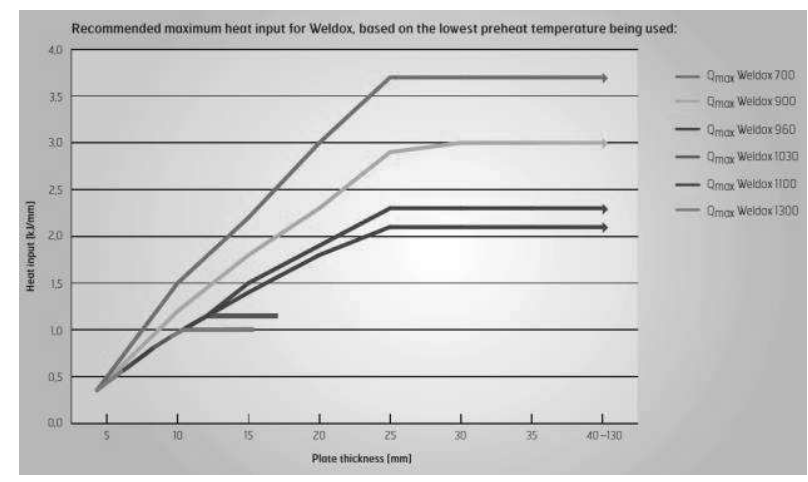

Fig. 1 Recommended beat input for welding [3]

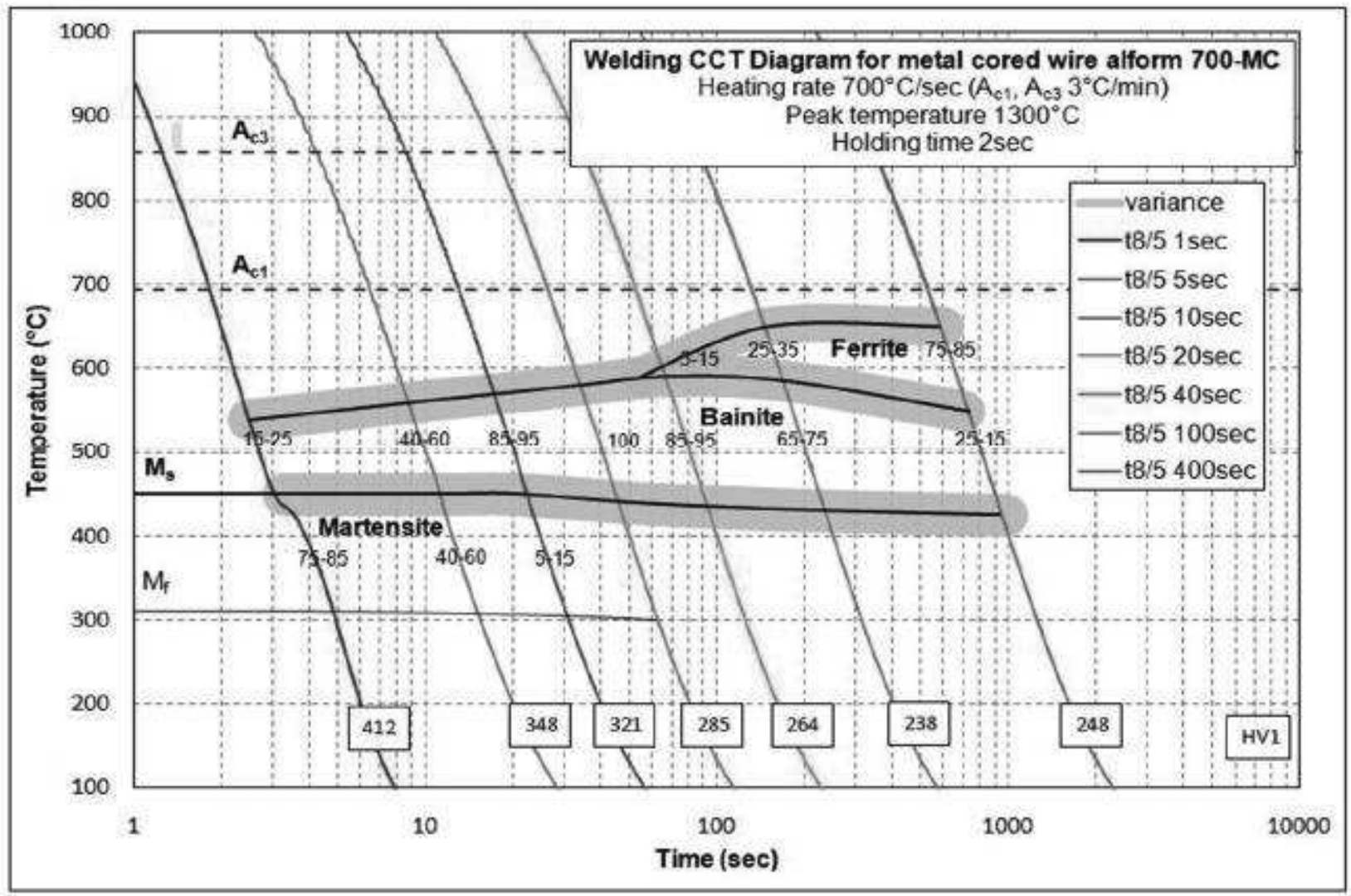

Fig. 2 t8/5 $_{8,5}$ rulting influence on material structure and hardness HV1 of weld metal $[1]$

Quality insuring and process repeatability requirements increases when higher yield strength steel is used as the parent material. This can be achieved with new, progressive welding methods, such as, welding with high energy density (laser, PAW), hybrid methods (laser-hybrid, plasma-hybrid) and modified arc methods (RapidWeld, Force Arc, CMT, ColdWeld, etc.) $[7,8]$ 
Each of these modern welding methods are suitable for the use of various types of welded product manufacturing - e.g. lot size, wall thickness, type of parent metal, etc. It is technically convenient to use the RapidWeld welding method for serial production of products with a wall thickness of $8 \mathrm{~mm}$ and high strength steel parent metal. This method is able to provide high quality welds with increases to productivity and reductions to production cost, all with minimal investment. The production cost reduction is connected with the limitations of chamfering expenses. It is possible to reduce or remove the included angle in butt welds with this method. $[7,8]$

It is possible to achieve an $8 \mathrm{~mm}$ deep penetration with the RapidWeld welding method and because of that, this method is greatly applicable for square groove welding. The correct welding parameters, travel angle of the torch, root gap, arc length and width must be correctly specified and performed to ensure a great weld quality or imperfections may occur. The adjustment of the travel angle is critical in this method, since if the torch is wrongly adjusted, the required penetration is not achieved.

This method is suitable for thick plate welding ( $t>$ $5 \mathrm{~mm}$ ), all steel grades, automatic or manual welding, long straight welds, single or double butt welds and for welding with a reduced included angle $\left(35^{\circ}\right.$ instead of common $45^{\circ}-60^{\circ}$ ). ForceArc uses high current and wire feeding speed. This combination is beneficial in the manufacturing process - deep penetration and high deposition rate. $[7,8]$

There is a ForceArc requirements on joint design and this method is not applicable for corner welding, hard to approach locations, and forced positions.

\section{Experiment}

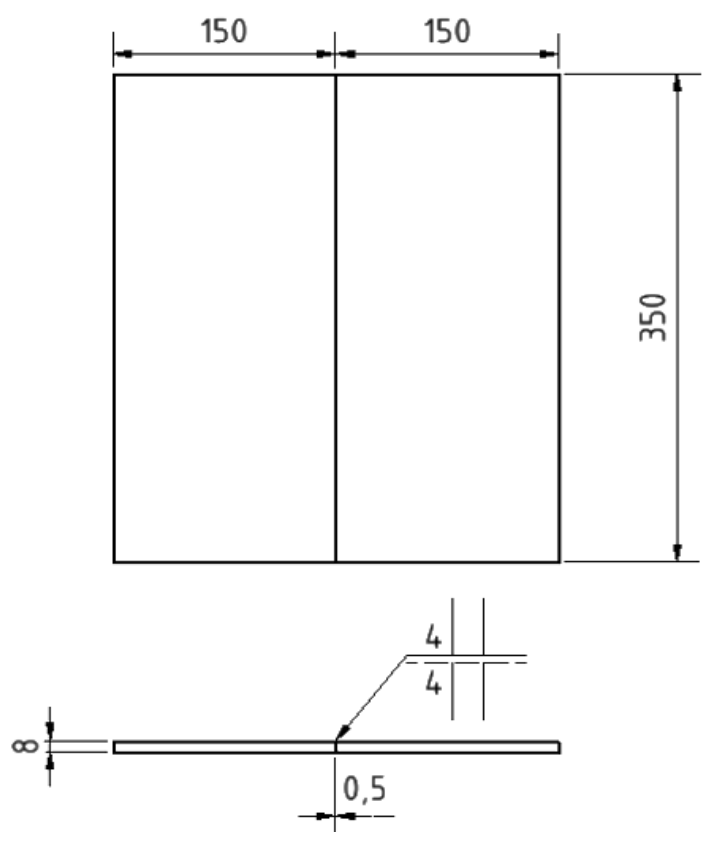

Fig. 3 Sample
The aim of this experiment was to assess the suitability of the RapidWeld welding method for S1100QL steel. The square groove 8I butt weld has been chosen for the experiment. The sample was welded in two weld passes. The joint design and welding sequence is found in Fig. 3.

Three identical welds were welded using the same technological procedure during the experiment. All welds were welded consecutively and the sample parent metal was gained from one plate with the same heat No., mechanical properties, and chemical composition.

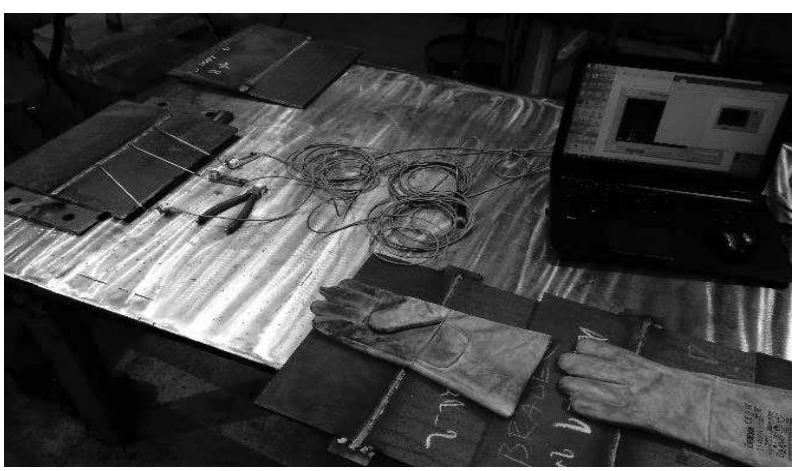

Fig. $4 t_{8 / 5}$ cooling time measurement with thermocouples and Vöst Alpine device

The assessment of the measurement suitability was based on joint hardness HV5 according to ISO 90151 , yield strength $\mathrm{Rp} 0.2$ and tensile strength $\mathrm{Rm}$ according to ISO 4136 and toughness KV2 according to ISO 9016.

The position of the specimens for each testing method in the welded sample is visible in Fig. 5.

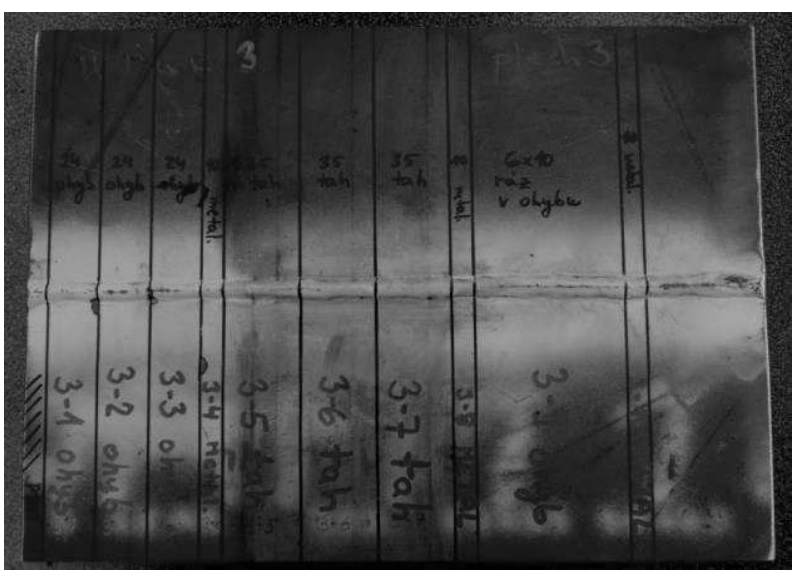

Fig. 5 Position of specimens in the welded sample

\subsection{Basic metal}

High strength steel S1100QL with a plate thickness of $8 \mathrm{~mm}$ was used as the sample parent metal for this experiment. Chemical composition and mechanical properties of the chosen steel was gained from Inspection document 3.1 according to ISO 10204. The chemical composition of S1100QL steel is found in Tab. 2 and mechanical properties in Tab.3. 
Tab. 2 Chemical composition of the parent metal, S1100QL

\begin{tabular}{|c|c|c|c|c|c|c|c|c|c|c|c|c|c|}
\hline Material & $\begin{array}{c}\mathrm{C} \\
{[\%]}\end{array}$ & $\mathbf{M n}$ & $\begin{array}{c}\mathrm{Si} \\
{[\%]}\end{array}$ & $\begin{array}{c}\mathbf{P} \\
{[\%]}\end{array}$ & $\begin{array}{c}\mathrm{S} \\
{[\%]}\end{array}$ & $\begin{array}{c}\mathrm{Cr} \\
{[\%]}\end{array}$ & $\begin{array}{c}\mathbf{M o} \\
{[\%]}\end{array}$ & $\begin{array}{c}\mathrm{Ni} \\
{[\%]}\end{array}$ & $\begin{array}{c}\mathrm{Nb} \\
{[\%]}\end{array}$ & $\begin{array}{c}\mathrm{Cu} \\
{[\%]}\end{array}$ & $\begin{array}{c}\mathbf{T i} \\
{[\%]}\end{array}$ & $\begin{array}{c}\mathbf{A l} \\
{[\%]}\end{array}$ & $\begin{array}{c}\mathbf{N} \\
{[\%]}\end{array}$ \\
\hline S1100QL & 0.17 & 1.10 & 0.25 & 0.009 & 0.001 & 0.65 & 0.61 & 0.04 & 0.31 & 0.03 & 0.004 & 0.097 & 0.0044 \\
\hline
\end{tabular}

Tab. 3 Mechanical properties of the parent metal, S1100QL

\begin{tabular}{|c|c|c|c|c|}
\hline Material & $\begin{array}{l}\text { Yield strength } \\
\mathbf{R}_{\mathrm{eH} \min }[\mathbf{M P a}]\end{array}$ & $\begin{array}{c}\text { Tensile strength } \\
\mathbf{R}_{\mathrm{m}}[\mathrm{MPa}]\end{array}$ & $\begin{array}{c}\text { Elongation } \\
\text { A [ } \%]\end{array}$ & $\begin{array}{c}\text { Impact energy } \\
\mathrm{KV}_{-40^{\circ} \mathrm{C}}[\mathrm{J}]\end{array}$ \\
\hline S1100QL & 1265 & 1401 & 8 & 36 \\
\hline
\end{tabular}

\subsection{Filler material}

Solid wire G 89 Mn4Ni2CrMo (Böhler Union X90) according to ISO 16834-A with a diameter of 1.2 $\mathrm{mm}$ was used as filler material. This filler material is recommended for the selected parent metal S1100QL by mobile crane producers. Chemical composition and mechanical properties of the chosen steel was gained from Inspection document 3.1 according to ISO 10204. Chemical composition of the filler material is in Tab.4 and mechanical properties are in Tab.5.

Tab. 4 Chemical composition of filler material G $89 \mathrm{Mn} 4 \mathrm{Ni2CrMo}$

\begin{tabular}{|c|c|c|c|c|c|c|c|c|c|c|c|c|c|}
\hline Material & $\begin{array}{c}\text { C } \\
{[\%]}\end{array}$ & $\begin{array}{c}\text { Mn } \\
{[\%]}\end{array}$ & $\begin{array}{c}\mathrm{Si} \\
{[\%]}\end{array}$ & $\begin{array}{c}\mathbf{P} \\
{[\%]}\end{array}$ & $\begin{array}{c}\mathrm{S} \\
{[\%]}\end{array}$ & $\begin{array}{c}\mathrm{Cr} \\
{[\%]}\end{array}$ & $\begin{array}{c}\mathbf{M} \% \\
{[\%]}\end{array}$ & $\begin{array}{c}\mathbf{N i} \\
{[\%]}\end{array}$ & $\begin{array}{c}\mathbf{V} \\
{[\%]}\end{array}$ & $\begin{array}{c}\mathbf{C u} \\
{[\%]}\end{array}$ & $\begin{array}{c}\mathbf{T i} \\
{[\%]}\end{array}$ & $\begin{array}{c}\mathbf{A l} \\
{[\%]}\end{array}$ & $\begin{array}{c}\mathrm{Zr} \\
{[\%]}\end{array}$ \\
\hline $\begin{array}{c}\text { G } 89 \\
\text { Mn4Ni2CrMo }\end{array}$ & 0.11 & 1.79 & 0.77 & 0.01 & 0.01 & 0.35 & 0.59 & 2.20 & $<0.01$ & 0.01 & 0.07 & $<0.01$ & $<0.01$ \\
\hline
\end{tabular}

Tab. 5 Mechanical properties of filler material G $89 \mathrm{Mn} 4 \mathrm{Ni2} \mathrm{CrMo}$

\begin{tabular}{|c|c|c|c|c|}
\hline Material & $\begin{array}{c}\text { Yield strength } \\
\mathbf{R}_{\mathbf{p 0 . 2}} \text { [MPa] }\end{array}$ & $\begin{array}{c}\text { Tensile strength } \\
\mathbf{R}_{\mathbf{m}}[\mathbf{M P a}]\end{array}$ & $\begin{array}{c}\text { Elongation } \\
\mathbf{A}[\%]\end{array}$ & $\begin{array}{c}\text { Impact energy } \\
\mathbf{K V}_{-60^{\circ} \mathbf{C}}[\mathbf{J}]\end{array}$ \\
\hline G 89 Mn4Ni2CrMo & $\geq 890$ & $950-1180$ & $\geq 15$ & $\geq 47$ \\
\hline
\end{tabular}

\subsection{Welding of the samples}

The modified manually operated GMAW Rapid-
Weld was used to weld the samples. Welding parameters, heat input and $\mathrm{t}_{8 / 5}$ calculated on WeldClass software are in the Tab. 6 .

Tab. 6 Process parameters

\begin{tabular}{|c|c|c|c|c|c|}
\hline $\begin{array}{c}\text { Layer } \\
\text { No. }\end{array}$ & $\begin{array}{c}\text { Current } \\
\mathbf{I}[\mathbf{A}]\end{array}$ & $\begin{array}{c}\text { Voltage } \\
\mathbf{U}[\mathbf{V}]\end{array}$ & $\begin{array}{c}\text { Welding speed } \\
\mathbf{V}_{\mathbf{w}}\left[\mathbf{c m} \cdot \mathbf{m i n}^{-1}\right]\end{array}$ & $\begin{array}{c}\text { Heat input } \\
\mathbf{Q}\left[\mathbf{k J} \cdot \mathbf{m m}^{-1}\right]\end{array}$ & $\begin{array}{c}\mathbf{t}_{8 / 5} \\
{[\mathbf{s}]}\end{array}$ \\
\hline 1 & $291-296$ & $33.0-33.6$ & 60 & $0.77-0.8$ & 10.8 \\
\hline 2 & $286-297$ & $32.6-33.2$ & 70 & $0.64-0.68$ & 7.7 \\
\hline
\end{tabular}

The shielding gas, ISO 14175 - M21- ArC - 18 $(82 \% \mathrm{Ar}, 18 \% \mathrm{CO} 2)$, with a gas flow of $121 . \mathrm{min}^{-1}$ was used. The arc welding power source, Cloos QUINEO TRONIC PULSE 450, was used for welding.

\section{Results and Discussion}

The method suitability evaluation was based on joint hardness HV5, yield strength $\mathrm{Rp}_{0.2}$, tensile strength $\mathrm{R}_{\mathrm{m}}$, and toughness $\mathrm{KV}_{2}$ assessment.

\subsection{The hardness measurement}

The hardness measurement was performed in accordance to standard ISO 9015-1, the location of measuring points follows the mentioned standard requirements (face - middle - root), see Fig. 6. One hardness measurement was performed for each sample.

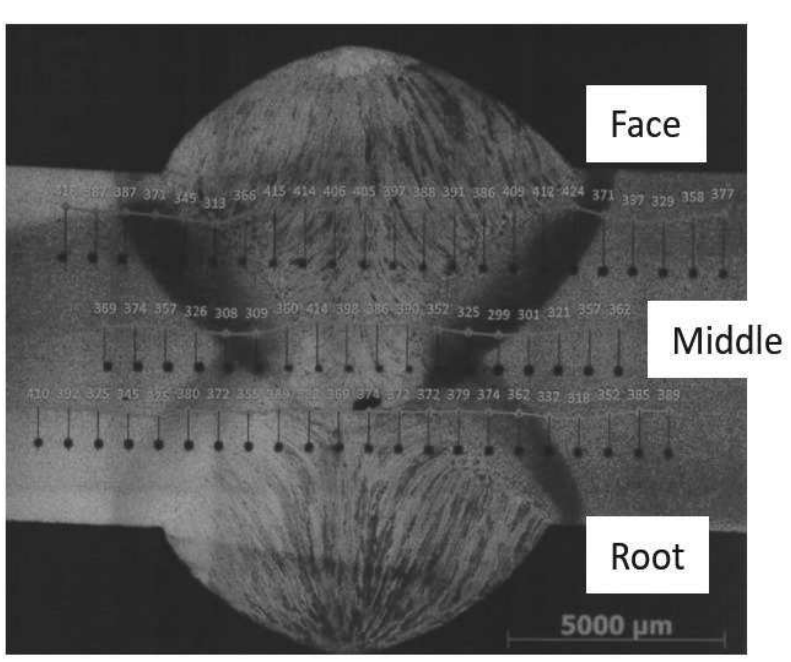

Fig. 6 HV 5 hardness measurement 
The hardness HV5 measurement was performed on the device Durascan $70 \mathrm{G}$. The HV5 hardness pro-gress for samples 1, 2 and 3 is on the Graph 1,2 and 3.

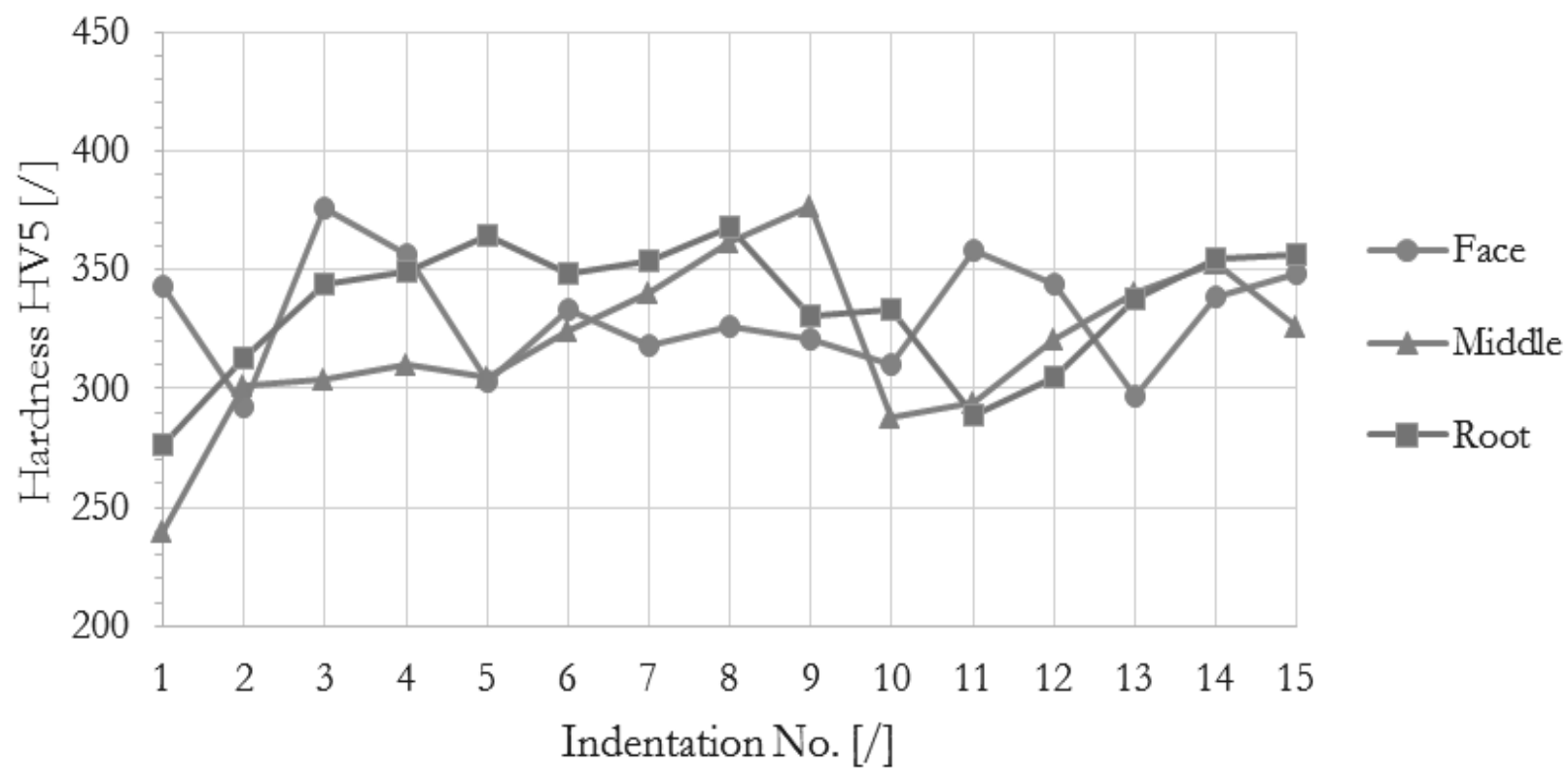

Graph 1 Sample 1, HV5 hardness

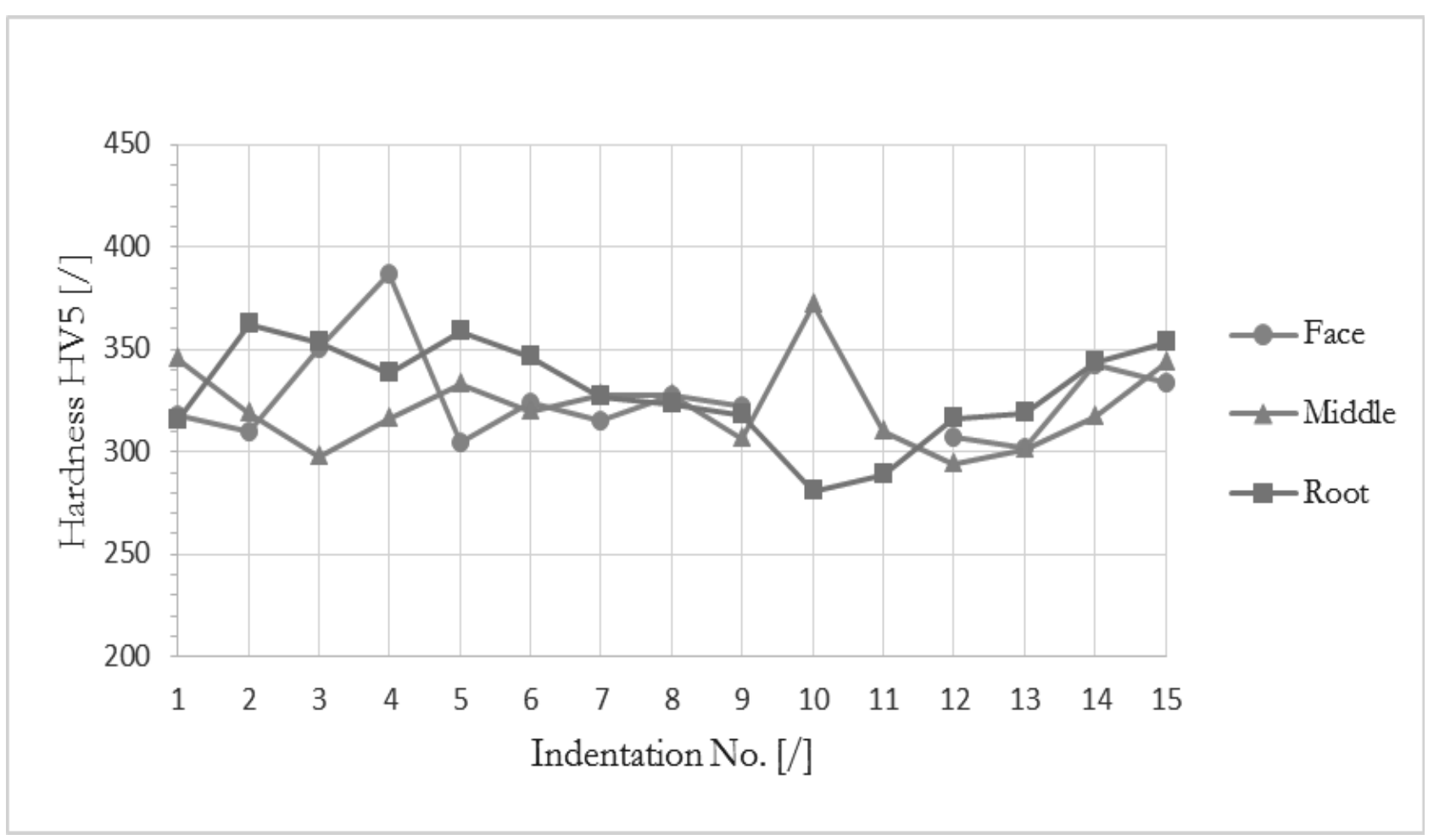

Graph 2 Sample 2, HV5 hardness 


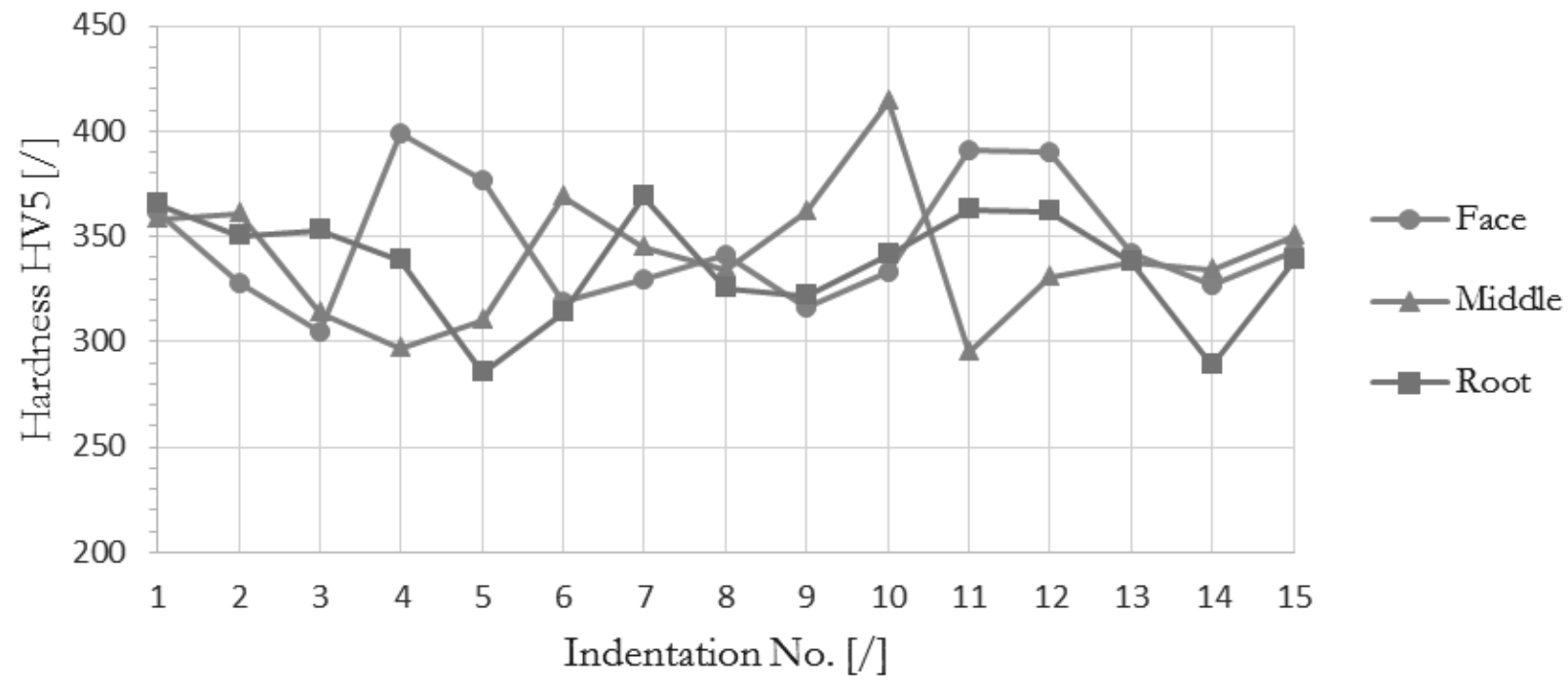

Graph 3 Sample 3, HV5 hardness

The values of hardness are without significant drops and peaks in the heat affected zone. These results confirm the great weldability of the selected base material. The presented hardness value deviation is caused by different HAZ properties. The maximal values of hardness are below 450HV5 limit and in accordance with the requirement. The hardness results in sample 1 are the lowest. The hardness value does not show significant differences in individual areas. The hardness HV5 did not exceed the maximum value in critical areas. The hardness also did not fall to a level where any softening would occur in any of the areas.

\subsection{Strengths assessment}

Transverse tensile strength test was performed in accordance with standard ISO 4136. The test was performed on a Zwick/ Roel Z250 device. One
Transverse tensile strength test was performed for each sample. Values of yield strength $\mathrm{Rp}_{0.2}$ and tensile strength $\mathrm{R}_{\mathrm{m}}$ are found in Tab. 7

Tab. 7 V alues of yield strength $\mathrm{R} p_{0.2}$ and tensile strength $\mathrm{R}_{m}$

\begin{tabular}{|c|c|c|c|}
\hline \multirow{2}{*}{ Position } & \multicolumn{3}{|c|}{ Yield strength $\mathbf{R}_{\mathbf{p} .2}[\mathrm{MPa}]$} \\
\cline { 2 - 4 } & $\mathbf{1}$ & $\mathbf{2}$ & $\mathbf{3}$ \\
\hline A & 1087.6 & 1050.6 & 1047.1 \\
\hline B & 1097.8 & & 1042.4 \\
\hline C & 1106.4 & 1036.6 & 1040.9 \\
\hline Average & 1097.3 & 1043.6 & 1043.5 \\
\hline
\end{tabular}

Resulting stress-strain diagram for Sample 1 is on in the Graph 4.

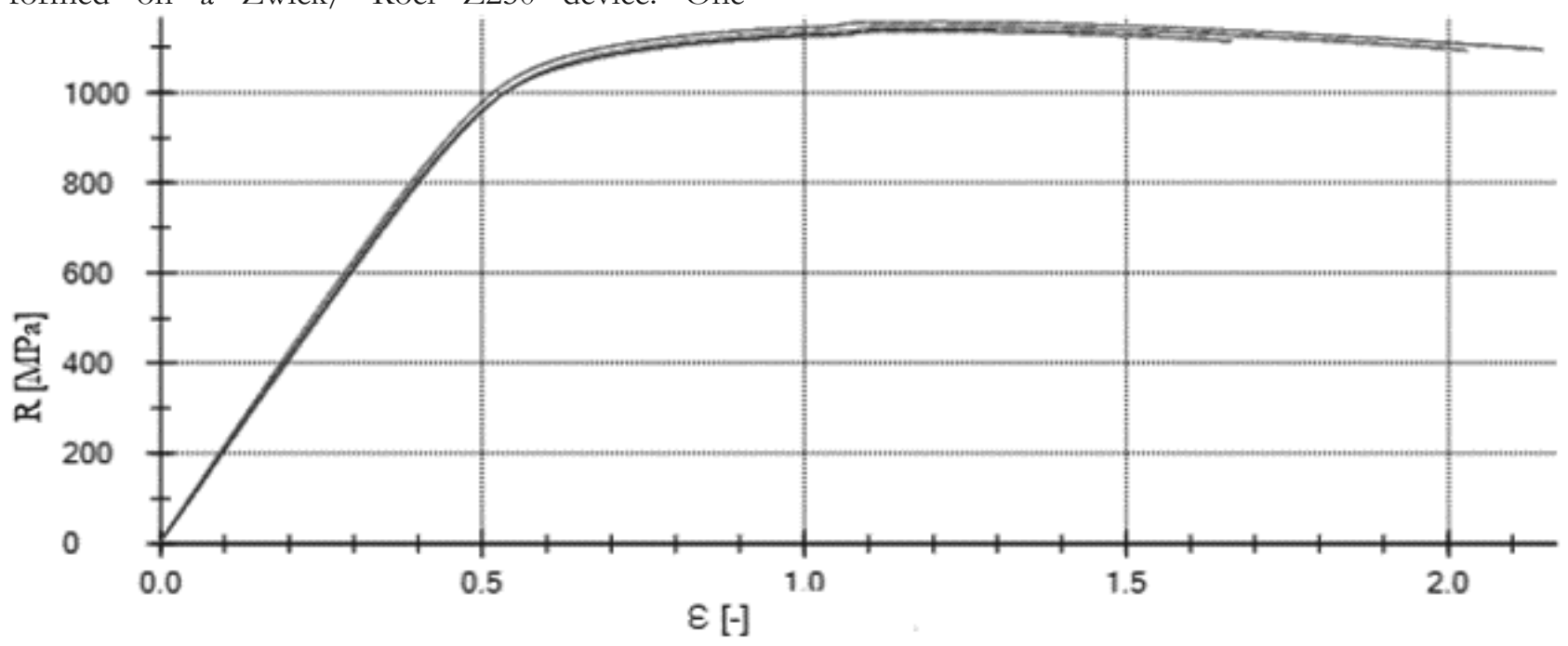

Graph 4 Resulting stress-strain diagram for Sample 1 
The obtained strength characteristics confirm the required strength of the welded joint for steel structures by ISO 15614-1 and mobile crane manufacturers. The small devitaion in strength values confirm the great weldability of the material.

\subsection{Toughness assessment}

Impact test was performed in accordance to standard ISO 9016. The test was performed on a DMG device. Three impact tests were performed for each sample. Values of toughness at $-40^{\circ} \mathrm{C}$ for each specimen are in Tab. 8.

Tab. 8 Toughness $K V_{2}$ values

\begin{tabular}{|c|c|c|c|}
\hline \multicolumn{4}{|c|}{ Toughness $\mathbf{K V}_{\mathbf{2}}[\mathrm{D}]$ at $\left[-\mathbf{4 0}{ }^{\circ} \mathrm{C}\right]$} \\
\hline \multirow{2}{*}{ Position } & \multicolumn{3}{|c|}{ Sample } \\
\cline { 2 - 4 } & 1 & 2 & 3 \\
\hline A & 80.4 & 27.1 & 37.1 \\
\hline B & 43.1 & 53.8 & 39.9 \\
\hline C & 40.5 & 37.5 & 29.6 \\
\hline Average & $\mathbf{5 4 . 7}$ & $\mathbf{3 9 . 5}$ & $\mathbf{3 5 . 5}$ \\
\hline
\end{tabular}

The dispersion of toughness value is significant for all the specimens, but the average value is similar for all of them. The minimal measured values (27J) are above requirement.

\section{Conclusion}

The research aimed on square groove welding of ultra-high strength steel is limited in scientific sphere in present. The obtained results of mechanical properties by Nowacky and col. [5] approaching with performed research published in this paper.

The mechanical properties of square groove welded joint correspond with the properties of welded joint with the single $\mathrm{V}$ groove. $[3,11]$

The main influence on the mechanical properties of welded joint is the used heat input and in consequences the cooling time $t_{8 / 5}$. The fulfill of the $t_{8 / 5}$ steel producer requirement [3] is critical for achieving of demanded mechanical properties.

The aim of this experiment was to evaluate the suitability of the deep penetration welding method (RapidWeld), for the use of square groove welding of high strength ultra-fine-grained steel. After suitability confirmation, it is possible to use this welding method to increase productivity, quality and safety in the mobile crane industry.

Suitability evaluation requirements were focused on mechanical properties of the resulting welded joint, which are most important when selecting welding technology used for fine-grained steel.

Maximum hardness value $450 \mathrm{HV} 5$ and hardness progress fulfill the requirement $(\leq 450 \mathrm{HV} 5)$. The hardness value does not show significant differences in individual areas. The HV5 was chosen for better readability of measurement and better documenting measurement results.

Strength characteristics (Yield strength $\mathrm{Rp}_{0.2}$ and Tensile strength $\mathrm{Rm}$ ) of the welded joint (combination of parent metal S1100QL and X90 filler material) fulfill the requirements of mobile crane producers. All measured Yield strength $\mathrm{R}_{0.2}$ values fulfill the requested $890 \mathrm{MPa}$ and Tensile strength $\mathrm{Rm}$ values 950MPa. According to gained values in Tab. 7 and Graph 3, the resulting strengths are similar.

Toughness $\mathrm{KV}_{2}$ values of welded joint fulfill standard EN 10025-6 requirement $\left(27 \mathrm{~J}\right.$ at $\left.-40^{\circ} \mathrm{C}\right)$.

The deep penetration welding method (RapidWeld) has fulfilled all suitable evaluation requirements for the selected parent and filler material combination. The use of the method, in combination with ultrafine grained high strength steel for square groove welding, has been qualified.

\section{References}

[1] KLEIN, M., SONNLEITNER, M., STIASZNY, P. (2012). Alform x-treme Innovation, Voestalpine Stahl, Austria

[2] EN 1011-2: (2001). Svarováni - Doporucení pro svarováni kovorých materiáli - Cást 2: Oblonkové svarováni feritickéch ocelí. 1. Praha: Český normalizační institut, ICS 25.160.10

[3] STEMNE, D., NARSTRÖM T., HRNJEZ, B. (2010). Welding handbook: a guide to better welding of Hardox and Weldox. Oxelösund: SSAB, ISBN 9789197857307.

[4] BRABEC, J., JEŽEK, Š., BENEŠ, L., KOLAŘ́ÍK, L., BERES, G. (2019). Metallurgy of the weld joints on the weldox 1100 steel realised with the laser hybrid technology, Colloquium, Vír, pp. 170-176. ISSN 1801-674X.

[5] NOWACKI, J., SAJEK A., MATKOWSKI, P. (2016). The influence of welding heat input on the microstructure of joints of S1100QL steel in one-pass welding. Archives of Civil and Mechanical Engineering. ISSN 16449665.

[6] BENEŠ, L., BRABEC, J., JEŽEK, Š. (2018) Svařování jemnozrnných konstrukčních ocelí $\mathrm{V}$ auto-jeřábové technice s ohledem na hodnotu parametru t8/5. Sbornik prédnášek z konference PROMATTEN „Progresivni materiály a tecbnologie (Advanced Materials and Tecbnologies)"; X. roč., Vidly - Vrbno pod Pradědem, pp. 28-32. ISBN 978-80-905947-4-6.

[7] Cloos, RapidWeld, Cloos Praha spol. s r.o.

[8] EWM, forceArc, EWM HIGHTEC WELDING GmbH 
[9] MICHNA, Š. (2012). Fyzika koviu, Ústí nad Labem, J. E. Purkyne University in Usti nad Labem, OPTYS spol.

[10] Bundesanstelt für Materilaprïfung, (2012). 1. alform welding day

[11] EGGER, R. (2012). Thermomechanically rolled beavy plates, Voestalpine Stahl, Austria

[12] BAM, (2012). 1st Alform welding day. Linz, Austria
[13] BLATNICKÁ, M., ŠAJGALÍK, M., SÁGA, M., BLATNICKÝ, M. (2018). Comparison of Residual Stress in High Strength Steel Sample before and after Laser Welding, Manufacturing Technology, pp. 369-371. ISSN 1213-2489.

[14] BARÉNYI, I., MAJERÍK, J. , BEZECNÝ, J., KRBAŤA, M., SEDLÁK, J., JAROŠ, A. (2019). Material and Technological Aspects while Processing of Selected Ultra High Strength Steel, Manufacturing Technology, pp. 184-189. ISSN 1213-2489. 